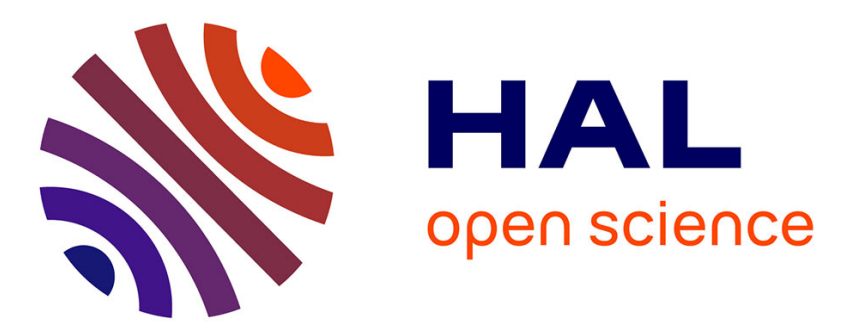

\title{
The Robo3 receptor, a key player in the development, evolution and function of commissural systems
}

François Friocourt, Alain Chédotal

\section{To cite this version:}

François Friocourt, Alain Chédotal. The Robo3 receptor, a key player in the development, evolution and function of commissural systems. Developmental Neurobiology, 2016, 10.1002/dneu.22478 . hal01445005

\section{HAL Id: hal-01445005 \\ https://hal.sorbonne-universite.fr/hal-01445005}

Submitted on 24 Jan 2017

HAL is a multi-disciplinary open access archive for the deposit and dissemination of scientific research documents, whether they are published or not. The documents may come from teaching and research institutions in France or abroad, or from public or private research centers.
L'archive ouverte pluridisciplinaire HAL, est destinée au dépôt et à la diffusion de documents scientifiques de niveau recherche, publiés ou non, émanant des établissements d'enseignement et de recherche français ou étrangers, des laboratoires publics ou privés. 
The Robo3 receptor, a key player in the development, evolution and function of commissural systems

Running title : Function and dysfunction of Robo3

François Friocourt ${ }^{1}$ and Alain Chédotal ${ }^{1,}$,

1 Sorbonne Universités, UPMC Univ Paris 06, INSERM, CNRS, Institut de la Vision, 17 Rue Moreau, 75012 Paris, France.

${ }^{*}$ Corresponding author:

Dr Alain Chédotal

Institut de la Vision, 17 tue Moreau, 75012, Paris, France

e-mail: alain.chedotal@inserm.fr

Phone : (+33)153462515

Fax : (+33)153462602

\section{Acknowledgements}

This work was supported by grants from the "Fondation pour la Recherche Médicale" (grant DEQ20120323700), the Agence Nationale de la Recherche (ANR-14-CE13-0004-01). It was performed in the frame of the LABEX

LIFESENSES (reference ANR-10-LABX-65) supported by French state funds 
managed by the ANR within the Investissements d'Avenir programme under reference ANR-11-IDEX-0004-02 


\section{ABSTRACT}

Roundabout receptors are known to mediate Slit-dependent repulsive signaling. However in vertebrates, mounting evidence suggest that Robo3 is an unconventional Robo receptor regarding both its expression and function. From its initial description, Robo3 receptor has been tightly associated with the development of specific axons, called commissural, that connect both sides of the nervous system. Many studies using transgenic mouse models showed that Robo3 expression is mandatory for commissural axon guidance to the floor plate. Moreover, mutations in human ROBO3 are responsible for a rare neurological disease in which patients also display midline crossing defects. Robo3 was initially thought to counteract Slit/Robo repulsion. However, recent studies support an alternative model where Robo3 potentiates midline attraction. These studies support a complex, central and multifaceted role of Robo3 in controlling the development of commissural circuits. Furthermore, the analysis of Robo3 evolution in vertebrates points out the specificity of this receptor in the mammalian lineage, suggesting mechanistic and functional divergence of Robo3 in mammals compared to a more traditional function in other vertebrates. Here, we review the current knowledge about Robo3 function, from the regulation of its expression to signaling. We also present evidence for a high variability of Robo3 splice variants in vertebrates.

Keywords: Axon guidance, Robo, Slit, receptor, commissure, HGPPS 


\section{INTRODUCTION}

The central nervous system of all species with bilateral symmetry (the socalled bilateria) contains two main types of projection neurons: some connected to neurons located on the same side than their cell body, others connected to the opposite side. The latter are called commissural neurons and they allow coordination and integration of information coming form both sides of the body, which is essential for multiple functions such as binocular vision, sound localization or integrated sensory-motor responses. Abnormal axon midline crossing during development can cause a whole range of neurological disorders. This is for instance the case of congenital mirror movements (CMMs) in which patients exhibit bilateral and symmetric movements when intending to perform an unilateral motor task (Meneret et al., 2015). In some patients, the motor cortex was found to be connected to motor neurons on both sides of the spinal cord, instead of the contralateral side only, although abnormal midline crossing at the level of the spinal cord and corpus callosum might also be involved. Abnormal connections of the motor cortex to the spinal cord motor neurons were also observed in patients having horizontal gaze palsy with progressive scoliosis disorder (HGPPS) (Jen et al., 2004). In these patients, a reduction of commissural projections in the hindbrain is associated with an absence of conjugate horizontal eye movements. In albino patients, the severe reduction of the contingent of visual axons projecting to the ipsilateral side of the brain (which is normally around $50 \%$ in humans) leads to a severe impairment of binocular vision (Neveu and Jeffery, 2007). Partial of complete corpus callosum agenesis (CCA) are some of the most common brain malformations in children (Paul, 2011) and can now be diagnosed as early as 20 weeks of gestation using magnetic resonance imaging (MRI) and in utero diffusion tensor imaging (Huang and Vasung, 2014). The genetic basis of CCA is still largely unknown and the deleterious neurological outcome is variable. Therefore, getting a better understanding of the mechanisms that control midline crossing by commissural axons should help understanding the etiology of these complex diseases. 
Basic neuroscientists as well have been fighting for decades to solve the midline crossing enigma and to characterize the cellular and molecular mechanisms involved (Tessier-Lavigne and Goodman, 1996; Chédotal, 2011). In the last quarter-century, ENU-based mutagenesis screens in C.elegans (Hedgecock et al., 1990), Drosophila (Seeger et al., 1993) and zebrafish (Karlstrom et al., 1996), together with biochemical and genetic studies in other vertebrate species have led to rapid progress and the identification of key receptors and ligands which control midline decussation (Tessier-Lavigne and Goodman, 1996; Chédotal, 2011). In all bilaterian species, some of these axon guidance molecules attract commissural axons to the midline when others expel or repel them away from it.

The Roundabout receptor (Robo) was first identified in Drosophila as the product of a gene whose mutation leads to multiple crossing and recrossing of commissural axons that wander around the nerve cord midline (Seeger et al., 1993). This receptor mediates axonal repulsion upon binding to its ligand Slit, which plays an important role in the midline crossing process (Kidd et al., 1999). Two other Robo genes are presented in drosophila, Robo2 and Robo3 and are also associated with Slit-mediated axon guidance (Rajagopalan et al., 2000). Robo homologues have since been identified in vertebrates were they also control midline crossing (Kidd et al., 1998). At least 4 Robo genes, Robo1-Robo4 exist in all vertebrates, sharing no orthology with drosophila Robo1-Robo3 genes as they derive from two rounds of duplication in vertebrate phylum (Evans and Bashaw, 2012; Zelina et al., 2014) (Figure 1). Three of them, Robo1, Robo2 and Robo3 being expressed in the CNS of vertebrates (Lee et al., 2001; Marillat et al., 2002; Camurri et al., 2004; Sundaresan et al., 2004). Robo1 and Robo2 were identified by homology with Drosophila Robo (Kidd et al., 1998; Brose et al., 1999), but Robo3, also known as Rig1, was found by differential display as a gene up-regulated in retinoblastoma-deficient cells (Yuan et al., 1999). Like all Robo receptors, Robo3 is a transmembrane receptor with an extracellular domain composed of five immunoglobulin (Ig) domains and three fibronectin type III (FNIII) repeats followed by a cytoplasmic domain containing 3-4 conserved motifs (CC) (Figure 1). Mounting evidence shows that Robo3 is one of the master 
regulators of midline crossing in vertebrates, with unique signaling properties, mechanisms of action and function. Here, we will summarize the current knowledge on Robo3 in the normal CNS and in neurological diseases.

\section{ROBO3 FUNCTION: FROM MOUSE TO FISH}

Robo3 expression in the vertebrate nervous system was first studied using in situ hybridization. In zebrafish, Robo3 is mostly expressed in the nervous system, including spinal cord, hindbrain, cerebellum, tectum with a low expression in retinal ganglion cells (Challa et al., 2001; Lee et al., 2001). This is also the case in xenopus tadpoles (Hocking et al., 2010). On the contrary, Robo3 expression pattern in mouse embryos appears extremely restricted in time and space, with a strong expression level in the dorsal spinal cord, hindbrain and cerebellum (Camurri et al., 2004). Immunohistochemical studies using Robo3-specific antibodies have shown that in the mouse, Robo3 is selectively expressed on developing commissural axons in the spinal cord, hindbrain, midbrain and epithalamus (Marillat et al., 2004; Sabatier et al., 2004; Belle et al., 2014) (Figure 2A). It was also detected in tangentially migrating neurons including cortical interneurons during their migration from the ganglionic eminence (Nguyen-Ba-Charvet et al., 2004; Barber et al., 2009; Kaneko et al., 2010; Cariboni et al., 2012), but it is not expressed by forebrain commissural neurons such as those of the anterior commissure or corpus callosum. Strikingly, Robo3 expression is rapidly downregulated after axons have crossed the ventral midline (the floor plate).

Understanding Robo3 receptor function was first addressed in the mouse through the generation of a Robo3 knockout (KO) line, by homologous recombination (Sabatier et al., 2004). The phenotypic analysis of Robo3 KO embryos revealed that they lack commissures in the posterior part of the CNS, including spinal cord, hindbrain and some midbrain commissures (Marillat et al., 2004; Sabatier et al., 2004; Tamada et al., 2008). This observation was surprising, as it could not be explained by a reduction of commissural axon midline repulsion as expected from a classic Roundabout receptor. Inspired by the drosophila Commissureless/Robo model (Keleman 
et al., 2002), it was then proposed that Robo3 receptor would inhibit repulsive signaling of Robo1/2 receptors in commissural axons before they cross the midline, thereby facilitating axonal extension towards the floor plate (Sabatier et al., 2004) Figure 2B. Accordingly, Robo1/2/3 triple mutants display partial rescue of commissural crossing in the spinal cord and some hindbrain nuclei (Sabatier et al., 2004; Di Meglio et al., 2008; Jaworski et al., 2010). However, other commissural axons, such as those of inferior olivary neurons (IO) still fail to cross in Robo1/2/3 triple mutants (Di Meglio et al., 2008). The possible mechanism underlying Robo3 inhibition of Robo1/2 repulsion remains unclear. One hypothesis was that Robo3 would compete with Robo1/2 for Slit binding (therefore titrating it) but the mouse Robo3 receptor does not bind Slit proteins (Mambetisaeva et al., 2005; Zelina et al., 2014). In vitro data also suggest that Robo3 might trigger Robo1/2 degradation (Li et al., 2014), but this hypothesis would need to be further explored in vivo. Finally, Robo3 could interfere with Robo1/2 downstream signaling pathways. An impairment of midline attraction provides an alternative explanation for the lack of commissures in Robo3 KO mice. Direct evidence supporting this hypothesis comes from the analysis of pontine neurons (PN), a class of precerebellar neurons which migrate from the rhombic lip in the dorsal hindbrain towards the floor plate. In Robo3 KO, pontine neurons are unable to reach the midline and their response to floor plate and netrin-1 attraction is abrogated (Zelina et al., 2014). It was shown that Netrin-1 does not directly bind to Robo3, but that it indirectly activates Robo3 through the deleted in colorectal carcinoma (DCC) receptor which can form a complex with Robo3 (Figure 2B).

Altogether, these models suggest that mammalian Robo3 promote midline attraction, directly or indirectly, which is surprising from an evolutionary point of view as it belong to a family of repulsive axon guidance receptors (Ypsilanti et al., 2010). Drosophila Robo2 receptor was also associated with midline attraction (Evans and Bashaw, 2010), yet the mechanism involved is different from what is proposed for mammalian Robo3 (Evans et al., 2015). Interestingly, Robo3 displays specific features in mammalian lineage compare to other vertebrates including the inability to bind Slits and important modifications of its intracellular domain associated with the loss of CC1 
domain (Figure 1C). This support distinct Robo3 signaling mechanisms between mammals and other vertebrates. How Robo3 receptors function in non-mammalian species is still largely unknown but they were shown to bind Slits, suggesting that they could mediate repulsion or titrate Slits from Robo1/2. Interestingly, in zebrafish, a large scale genetic screen for genes controlling embryo motility (Granato et al., 1996) identified the twitch twice mutant (twt) which exhibits abnormal escape response. It was later found that twt mutants carry mutations in the Robo3 gene (Burgess et al., 2009). In these fish, the motor response defect is probably associated with misguidance of hindbrain Mauthner axons that fail to cross the midline. Likewise, overexpression of Robo3 in these cells using a heat-shock transgenic line induces midline recrossing of Mauthner cells axon (Zelina et al., 2014). These data suggest that fish Robo3 might also enhance midline attraction. However, in zebrafish, Robo3 is also expressed by longitudinal and ipsilaterally projecting axons where it seems to repress Robo2-mediated midline repulsion (Schweitzer et al., 2013). Likewise, Robo2 and Robo3 influence the lateral positioning of post-optic commissure, in an opposite manner (Devine and Key, 2008). These results suggest that in zebrafish and other non-mammals, Robo3 could function as an anti-repulsive receptor. Interestingly, there is also evidence in zebrafish and xenopus, that Robo3 might control the development of RGC dendrites and apical process retraction (Hocking et al., 2010; Wong et al., 2012). These data suggest that in non-mammals, Robo3 function is more diverse than in mammals and varies between neurons.

The analysis of Robo3 KO and Robo3 conditional KO mice showed that the axons that become unable to cross the midline in absence of Robo3, still connect to their appropriate targets but on the ipsilateral side (Marillat et al., 2004; Comer et al., 2015). The physiological impact of this ipsilateral rewiring has been investigated in the cerebellum and auditory system. The inferior olive contains commissural neurons which project their axons (the climbing fibers) to Purkinje cells (PCs) in the contralateral cerebellum. In the adult, one $P C$ is innervated by a single climbing fiber. However, during postnatal development, there is a transient phase of multiple innervation during which 3- 
5 climbing fibers synapse on the same PC (Crepel et al., 1976). Activitydependent synaptic elimination is completed by the end of the second postnatal week. Interestingly, Robo3-deficient olivary axons aberrantly project to the ipsilateral cerebellum and exhibit severe and permanent motor deficits. However, CF elimination still occurs and PC responses to CF stimulation are not affected (Badura et al., 2013). A different outcome of ipsilateral rewiring was described in the auditory system. Globular bushy cells (GBCs) in the ventral cochlear nucleus receive inputs from the inner ear and project onto neurons of the medial nucleus of the trapezoid body (MNTB) in the opposite side (Borst and Soria van Hoeve, 2012). The very large synapse of GBC axons on MNTB neurons is called calyx of Held and after a transient phase of multiple innervation during development, the adult MNTB neurons becomes mono-innervated. This circuit plays a major role in sound localization. In absence of Robo3, GBC axons project to the ipsilateral MNTB (Renier et al., 2010; Michalski et al., 2013). Patch-clamp recording showed that many MNTB neurons remain multi-innervated and synaptic transmission and release are significantly altered. This shows that in some cases, axons that are prevented from crossing the midline might stay in an immature stage (Michalski et al., 2013), suggesting that the lack of Robo3, which is not expressed during synaptogenesis, might have some long-term functional impact on neuronal circuits. Importantly, the lack of Robo3 has even more drastic consequences for the conventional Robo3 KO mice as they all die a few hours after birth. It was found that lethality is most likely due to a decoupling of bilateral hindbrain premotor respiratory rhythm generators, which control the activity of phrenic nerve motor neurons innervating diaphragm muscles. In Robo3 KO, left-right rhythms are asynchronous and asymmetric diaphragm contractions severely perturb breathing (Bouvier et al., 2010).

\section{ROBO3 MUTATIONS IN HUMAN CAUSE THE HGPPS SYNDROME}

Shortly after Robo3 was characterized in the mouse, a genetic study of human patients suffering from a rare neurological disorder name HGPPS (Jen et al., 2004), identified ROBO3 as the causal gene. HGPPS is characterized 
by an absence of conjugate horizontal eye movements associated to a severe progressive scoliosis developing in childhood and adolescence.

Frequent consanguinity in patient families, and the absence of any symptoms in preceding generations suggested autosomal recessive inheritance. Genetic analysis first mapped the disorder locus on chromosome 11q23-25 (Jen et al., 2002). Further analysis identified multiple mutations in ROBO3 gene, homozygous in most HGPPS patients and heterozygous in non-affected relatives (Jen et al., 2004). Subsequent genetic studies of HGPPS individual has increased the list of $R O B O 3$ mutations associated with HGPPS disorder, all listed in Table1 (Jen et al., 2004; Amoiridis et al., 2006; Chan et al., 2006; Sicotte et al., 2006; Haller et al., 2008; Khan et al., 2008; Abu-Amero et al., 2009; Amouri et al., 2009; Volk et al., 2011; $\mathrm{Ng}$ et al., 2011; Wang et al., 2013; Yamada et al., 2015; Fernández-Vega Cueto et al., 2016). Surprisingly, the mutations are highly diverse, and the positions of the mutated amino acids spread along the $\mathrm{ROBO} 3$ protein (Figure $3 \mathrm{~B}$ ). Some mutations are predicted to induce a premature stop-codon, associated with expression of a truncated protein or mRNA degradation via nonsense mediated decay (NMD). In these cases, the absence of commissures in HGPPS patients could be easily explained by the absence of $\mathrm{ROBO} 3$ protein, as observed in Robo3 $\mathrm{KO}$ mice. However, most mutations are missense variants affecting multiple subdomains of the $\mathrm{ROBO} 3$ receptor (Figure $3 \mathrm{~B}$ ). Some variants impact $\mathrm{ROBO} 3$ targeting to the membrane or $\mathrm{ROBO} 3$ conformation leading to receptor degradation (Wang et al., 2013), but the consequences of most missense mutations on $\mathrm{ROBO} 3$ expression and function remain to be investigated. Additionally, numerous $\mathrm{ROBO} 3$ variants have been detected in a large-scale sequencing project ((Auton et al., 2015); Ensembl 84), most being rare variants when population frequency data was available. These variants are equally distributed along the $\mathrm{ROBO} 3$ sequence, with important accumulation of missense and frameshift mutations in the last exons coding for the C-terminal part of the receptor. This observation contrasts with HGPPS-associated variants, which are mostly located on the extracellular part of the protein. This difference suggests an important role of the extracellular domain in $\mathrm{ROBO}$ function. 
Although no detailed neuroanatomical study of the organization of the CNS of $R O B O 3$ patients was performed, they seem to exhibit commissural defects as Robo3 mutant mice, with one important difference, which is an apparently normal postnatal viability (there is not yet any evidence linking ROBO3 mutations to sudden death syndrome). The pontine nuclei is hypoplastic, which, as in Robo3 $\mathrm{KO}$ mice, is most likely due to the aborted ventral migration and dorsal spreading of these neurons along the hindbrain surface (Zelina et al., 2014). Likewise, diffusion tensor imaging and physiological studies showed that the corticospinal tract connecting the motor cortex to motor neurons project ipsilaterally instead of contralaterally in HGGPS patients (Jen et al., 2004; Bosley et al., 2005; Amoiridis et al., 2006). This is also the case of ascending sensory inputs from the spinal cord to the brain (Haller et al., 2008). The lack of CST decussation is surprising as, in the mouse, Robo3 is not expressed by projection neurons of the motor cortex (Barber et al., 2009). Although Robo3 expression in the developing CST has not been tested, it is likely that CST crossing defects are secondary and probably linked to an abnormal development of the ventral midline. Unfortunately, Robo3 KO mice die at birth precluding from analyzing CST projections, which enter the spinal cord postnatally. The origin of scoliosis onset in HGPPS patients is unknown. Neuromuscular disorder or imbalance in posture control pathways with vestibular system defects have been proposed to cause scoliosis (Ouellet and Odent, 2013), but no model is available to test this hypothesis. By contrast, horizontal gaze palsy is probably caused by commissural defects at the level of the hindbrain. A selective perturbation of horizontal eye movement in mice, mimicking what is found in HGPPS patients, was obtained using conditional Robo3 KO. The absence of Robo3, prevents the development of the olivocerebellar commissure (Badura et al., 2013) and of the commissural connections between abducens interneurons and the principal oculomotor (PO) nucleus (Renier et al., 2010) and impairs horizontal compensatory eye movements (Figure 3C-D) , suggesting that these two circuits might be altered in humans.

In addition to HGPPS, there is evidence for $R O B O 3$ association with psychiatric or developmental disorders such as a correlation of certain 
widespread intronic polymorphism with Autism (Anitha et al., 2008; Suda et al., 2011). Dys-regulation of Robo3 has also been reported in models of peripheral nerve injury, hypothyroidism and rheumatoid arthritis (Denk et al., 2010; Alvarado et al., 2013; Shiraki et al., 2016). The functional relevance of these modifications is still unknown.

\section{STRUCTURAL AND FUNCTIONAL DIVERSITY OF ROBO3 ISOFORMS}

Like most receptors, multiple isoforms of Robo3 receptor have been described (Figure 4A). Two alternative first exons have been identified in zebrafish, mouse and human, leading to two $\mathrm{N}$-terminal protein isoforms (Camurri et al., 2005; Challa et al., 2005). These $\mathrm{N}$-terminal isoforms are referred to as Robo3A and Robo3B (Figure 4A). Although both isoforms display a signal peptide and are at the membrane, little is known about the expression pattern and biological function of these two variants. Additionally, an alternative intron retention has been identified in mouse embryonic dorsal spinal cord full-length cDNA collection (Chen et al., 2008). Alternative retention of intron 26 during Robo3 mRNA splicing inserts a premature stop codon shortly after the CC3 domain, resulting in a shorter version of Robo3 receptor (Figure 4B). The two C-terminal isoforms are called Robo3.1 and Robo3.2 (Figure 4A). The comparative analysis of their expression pattern in the spinal cord of mouse embryos using Robo3.1 and Robo3.2 specific antibodies showed that Robo3.1 is only expressed in pre-crossing commissural axons and immediately down regulated as they reach the midline, whereas Robo3.2 is transiently expressed in post-crossing axons, immediately after midline crossing (Chen et al., 2008; Colak et al., 2013). This differential expression was attributed to Robo3.2 mRNA translocation and local translation in post crossing commissural axons. Intron retention in Robo3.2 mRNA is associated with nonsense-mediated decay (NMD), leading to elimination of this transcript shortly after translation, resulting in transient expression of this isoform (Colak et al., 2013). However, no mechanism has been proposed yet to explain Robo3.2 mRNA protection from NMD prior floor plate induced local translation. Furthermore, functional studies showed that 
only Robo3.1 is able to restore midline attraction in Robo3-KO rescue experiments (Chen et al., 2008). Robo3.2 has been proposed to participate to post-crossing axons midline repulsion (Chen et al., 2008; Colak et al., 2013), although functional evidences are still weak and no mechanism is proposed to explain this repulsive action considering that neither Robo3 isoform binds Slits (Zelina et al., 2014). An alternative possibility would be that intron 26 retention is a mechanism that inactivates Robo3.1 expression and therefore decrease midline attraction.

Here we focus on the phylogenic conservation of Robo3.1/Robo3.2 variants in vertebrates, which had not yet been addressed. As mentioned before, Robo3.2 has only been identified in mouse and rat embryonic cDNA banks (NCBI database, respectively AF060570.1 and NM_001108135.1), but never been described in human or any other species. However it is possible to forecast this variant from existing Robo3 gene sequences. On the one hand, we collected sequences of Robo3.1 proteins in Ensembl and NCBI databases. On the other hand we generated predicted Robo3.2 protein sequences by doing artificial intron26 retention from vertebrates Robo3 genes. Alignment of the C-terminal parts of Robo3.1 and Robo3.2 proteins are presented in Figure 4. We found that Robo3.1 is highly conserved in vertebrate species (60\% identity between residues 1319 to 1386, see Figure 4C). In contrast, predicted Robo3.2 sequences are highly variable (17\% identity between residues 1319 to 1351 , Figure 4D). This difference is even present between closely related mammals (see rabbit, mouse and marmot sequences, Figure 4D), demonstrating poor conservation of this intron between mammals. Such variability does not seem to support a conserved functional role of Robo3.2 variants widely in vertebrate axon guidance. Moreover, intron 26 splicing sites appear to be modified in glires phylum (a group of mammals including mouse, rat and rabbit) leading to an elongation of 8 amino acids at the splicing site (Figure 4C). Both versions of intron 26 splicing can even be found in some glires species like in the rabbit (Ensembl84 database: ENSOCUT00000005842 and ENSOCUT00000002640). This observation suggests that intron 26 splicing is divergent in glires, and particularly in rodents, and therefore might be more 
likely to give intron retention during splicing. Altogether, this suggests that Robo3.2 is most likely a rodent-specific isoform, belonging to lineage-specific alternative splicing category (Necsulea and Kaessmann, 2014).

\section{ROBO3 GENE EXPRESSION IS TIGHTLY REGULATED}

In addition to sequence and splice variation, Robo3 receptor expression is tightly regulated at different levels including transcriptional and translational regulation. As discussed before, Robo3 receptor is transiently expressed by commissural axons before they cross the midline, and rapidly down-regulated shortly after crossing (Marillat et al., 2004). This expression in a narrow developmental window and in restricted neuronal populations would support a basal transcriptional repression of this gene. Accordingly, Robo3 was first identified in mRNA extracts from Retinoblastoma protein (RB) knockout mouse embryos, where the transcriptional regulator $\mathrm{RB}$ protein is absent (Yuan et al., 1999). Luciferase assay with Robo3 promoter confirmed that RB induces a basal repression of Robo3 transcription (Yuan et al., 2002). Likewise, Robo3 up-regulation was detected in embryonic fibroblast cultures from mice deficient for the ubiquitous transcription factor Sp3 (Stielow et al., 2010). Sp3 is associated with gene silencing via heterochromatin formation and inhibition of RNApol-II effective transcription (Valin and Gill, 2013). Loosening of Robo3 constitutive repression could be induced by the transcription factor Pax2, binding to RB and inhibiting its repression activity on Robo3 (Yuan et al., 2002). However, Pax2 is not specific of commissural neurons (Wehr and Gruss, 1996) and no commissural phenotype was reported in Pax2 knockout (Torres et al., 1995), suggesting other transcription factors are certainly involved in this release of inhibition.

The genetic program controlling Robo3 expression in commissural neurons is still unknown, although several transcription factors (TFs) that either repress or induce its expression in some neurons have been identified (Chédotal, 2014). In the mouse spinal cord, ipsilateral and contralateral projecting 
interneurons are intermingled (Goulding, 2009), and Robo3 expression in these neurons is directly correlated to contralateral projection. For example, d11 interneurons expressing Robo3 are commissural interneurons (called dl1c), whereas others stay ipsilateral (called dl1i) (Wilson et al., 2008). This duality is controlled by TFs differential expression regulating Robo3 expression: LIM homeobox TFs Lhx2 and Lhx9 expression (Wilson et al., 2008), and upstream Barhl2 expression (Ding et al., 2012) (Figure 5A). Lhx2 can directly bind to Robo3 intronic region (Intron1) and possibly induce its expression in a dose-dependent manner (Wilson et al., 2008). This potential activation depends on other factors controlling Robo 3 chromatin accessibility as Lhx2 does not bind to the Robo3 gene in thalamic neurons compare to spinal cord neurons (Marcos-Mondejar et al., 2012). However, this transcriptional cascade cannot be extended to all commissural systems as Lhx2 is only expressed by a sub-population of commissural neurons in the spinal cord, and is equally expressed by contralateral and ipsilateral neurons in the midbrain (Wilson et al., 2008; Inamata and Shirasaki, 2014).

In the mouse midbrain and hindbrain, neurons derived from progenitors expressing Developing Brain homeobox protein 1 (Dbx1) express Robo3 and send commissural projections (Bouvier et al., 2010; Inamata and Shirasaki, 2014). Overexpression and silencing experiments in midbrain showed that the Dbx1 TF is necessary and sufficient to trigger Robo3 expression in neurons and midline crossing (Inamata and Shirasaki, 2014). Dbx1 regulation of Robo3 expression acts through Even-skipped homeobox 2 (Evx2)(Figure 5A), but weather this is direct or not is still unclear. Interestingly, this correlates with studies showing that Dbx1-derived spinal cord V0 commissural neurons express Evx1/2 TFs and that deletion of Dbx1 prevent midline crossing (Moran-Rivard et al., 2001; Pierani et al., 2001). This suggests that Dbx1 and Evx TFs might also control Robo3 expression in some spinal cord interneurons population, representing an important Robo3 gene regulatory pathway. Other important players controlling Robo3 expression have been identified in the mouse, including Hox TFs. As it has been shown for other Robos (Geisen et al., 2008), Hox genes are necessary to induce Robo3 expression. In Hoxa2 deficient mice, Robo3 expression in cochlear nucleus 
neurons is altered and these neurons send aberrant projections to the ipsilateral MNTB (Di Bonito et al., 2013). However, the association of these TFs with Robo3 expression in non-mammalian vertebrates has not been investigated yet.

In parallel of these findings, diverse TFs were found to maintain ipsilateral targeting of axons by repressing Robo3 expression in various vertebrates (Marion et al., 2005; Escalante et al., 2013; Schweitzer et al., 2013). Both in chicken and mouse spinal cord, over-expression of zinc finger protein Zic2 induces strong reduction of Robo3 expression (Escalante et al., 2013). As a consequence, the down-regulation of Zic2 in dILB ipsilateral interneurons in the mouse spinal cord induces Robo3 up-regulation and contralateral projections. Correspondingly, Zic2 overexpression in chicken dl1 and dl2 contralateral interneurons induces ipsilateral projections (Escalante et al., 2013). In mammillary body neurons, the absence of single-minded proteins Sim1 and Sim2 TFs induces Robo3 up-regulation and axon midline attraction in the mouse (Marion et al., 2005). Likewise, in zebrafish, Robo3 receptor expression in hypothalamo-spinal axons is up-regulated in Sim1a mutants (Schweitzer et al., 2013). However, how Sim1/2 or Zic2 suppress Robo3 expression is still unknown.

Altogether, these different results present multiple regulatory networks of Robo3, based on combinatorial expression of enhancing and repressing TFs (Figure 5A). Further evidence supporting the heterogeneity of the molecular mechanisms regulating Robo3 expression comes from the analysis of posttranscriptional regulation in pre-cerebellar nuclei (Kuwako et al., 2010). Inferior olive (IO), lateral reticular nucleus (LRN) and external cuneatus nucleus (ECN) precerebellar neurons express the RNA-binding protein Musashi 1 (Msi1), which binds to Robo3 mRNA and recruits it to heavy polysomes (Figure 5B). In Msi1-deficient animals, IO, LRN and ECN neurons do not cross midline due to insufficient Robo3 expression, but surprisingly other commissural projections in the pons and spinal cord remain unaffected (Kuwako et al., 2010). This suggests that different RNA-binding proteins might influence the post-transcriptional regulation of Robo3 in various types of commissural neurons. Of note, nothing is known about the mechanisms 
responsible for the rapid silencing of Robo3 expression in post-crossing axons.

\section{CONCLUSION AND PERSPECTIVES}

Many questions about Robo3 receptor function and mechanism of action remain to be answered.

First, the identity of the Robo3 ligand(s) is still unknown in mammals as neither Netrin-1 nor Slits bind to it (Zelina et al., 2014). It was recently proposed that neural epidermal growth factor-like-like 2 (NELL2), a glycoprotein secreted by motor neurons, is a Robo3 ligand (Jaworski et al., 2015) mediating repulsion. However no clear axon guidance phenotype is associated with NELL2 deletion in mice and how Robo3 receptor would transduce repulsive signaling remains unclear. Furthermore, NELL2 is not expressed by the floor plate and can't mediate Robo3 attractive activity. Another molecule, Secreted Frizzled Related Protein (SFRP), has been shown to bind to ROBO3 in pancreatic cancer cells (Han et al., 2015), but the physiological relevance is unknown. As a member of the IgCAM protein family, Robo3 could interact with many different receptors, including itself. Potential Robo3 oligomerisation could affect Robo3 activity and downstream signaling, as proposed for other Robo receptors (Hohenester, 2008; Zakrys et al., 2014). Heterophylic interaction with Robo1 have been reported (Camurri et al., 2005). Last but not least, Robo3 interacts with DCC via its intracellular domain (Zelina et al., 2014),

What are the components of the intracellular signaling cascade downstream of Robo3? Robo3 intracellular domain can be phosphorylated by different proteins, including Src-family kinases and protein kinase C (Zelina et al., 2014; Samelson et al., 2015). And strong divergence of Robo3 intracellular domain, with the $\mathrm{CC} 1$ domain loss in mammals, suggests that Robo3 signaling pathways differ from other Robo receptors (Figure1C). Yet, there is no clear and direct association of Robo3 with any intracellular signaling cascade. 
How Robo3 functions in non-mammalian species is also largely unknown. Unlike mammals, non-mammalian Robo3 receptors bind and respond to Slits (Zelina et al., 2014), and their intracellular domain is more similar to other Robo receptors (Figure 1C). In non-mammals, Robo3 expression does not seems to be restricted to caudal commissural neurons, and it was found in retinal ganglion cells, ipsilaterally projecting neurons or muscles (Challa et al., 2001; Hocking et al., 2010; Wong et al., 2012; Schweitzer et al., 2013). In Robo3 mutant zebrafish, commissural defects are variable and primarily affects Mauthner neurons (Burgess et al., 2009) and ipsilateral axons (Schweitzer et al., 2013). Last, injection of Robo3 morpholinos in Xenopus leads to axonal fasciculation defects (Devine and Key, 2008), supporting additional functions for this receptor outside of midline axon guidance.

In conclusion, a better understanding of Robo3 function, its regulation and downstream signaling pathways will shed new light on our knowledge of the molecular mechanisms controlling the development of commissural circuits and their evolution in vertebrates.

\section{REFERENCES}

Abu-Amero KK, al Dhalaan H, al Zayed Z, Hellani A, Bosley TM. 2009. Five new consanguineous families with horizontal gaze palsy and progressive scoliosis and novel ROBO3 mutations. J Neurol Sci 276:22-6.

Alvarado S, Tajerian M, Millecamps M, Suderman M, Stone LS, Szyf M. 2013. Peripheral nerve injury is accompanied by chronic transcriptome-wide changes in the mouse prefrontal cortex. Mol Pain 9:21.

Amoiridis G, Tzagournissakis M, Christodoulou P, Karampekios S, Latsoudis $\mathrm{H}$, Panou T, Simos P, Plaitakis A. 2006. Patients with horizontal gaze palsy and progressive scoliosis due to $\mathrm{ROBO} 3 \mathrm{E} 319 \mathrm{~K}$ mutation have both uncrossed and crossed central nervous system pathways and perform normally on neuropsychological testing. J Neurol Neurosurg 
Psychiatry 77:1047-53.

Amouri R, Nehdi H, Bouhlal Y, Kefi M, Larnaout A, Hentati F c\}al. 2009. Allelic ROBO3 heterogeneity in Tunisian patients with horizontal gaze palsy with progressive scoliosis. J Mol Neurosci 39:337-41.

Anitha A, Nakamura K, Yamada K, Suda S, Thanseem I, Tsujii M, Iwayama Y, Hattori E, Toyota T, Miyachi T, Iwata Y, Suzuki K, Matsuzaki H, Kawai M, Sekine Y, Tsuchiya K, Sugihara GI, Ouchi Y, Sugiyama T, Koizumi K, Higashida H, Takei N, Yoshikawa T, Mori N. 2008. Genetic analyses of Roundabout (ROBO) axon guidance receptors in autism. Am J Med Genet Part B Neuropsychiatr Genet 147:1019-1027.

Auton A, Abecasis GR, Altshuler DM, Durbin RM, Bentley DR, Chakravarti A, Clark AG, Donnelly P, Eichler EE, Flicek P, Gabriel SB, Gibbs RA, Green ED, Hurles ME, Knoppers BM, Korbel JO, Lander ES, Lee C, Lehrach H, Mardis ER, Marth GT, McVean GA, Nickerson DA, Schmidt JP, Sherry ST, Wang J, Wilson RK, Boerwinkle E, Doddapaneni H, Han Y, Korchina V, Kovar C, Lee S, Muzny D, Reid JG, Zhu Y, Chang Y, Feng Q, Fang X, Guo X, Jian M, Jiang H, Jin X, Lan T, Li G, Li J, Li Y, Liu S, Liu X, Lu Y, Ma X, Tang M, Wang B, Wang G, Wu H, Wu R, Xu X, Yin Y, Zhang D, Zhang W, Zhao J, Zhao M, Zheng X, Gupta N, Gharani N, Toji LH, Gerry NP, Resch AM, Barker J, Clarke L, Gil L, Hunt SE, Kelman G, Kulesha E, Leinonen R, McLaren WM, Radhakrishnan R, Roa A, Smirnov D, Smith RE, Streeter I, Thormann A, Toneva I, Vaughan B, Zheng-Bradley X, Grocock R, Humphray S, James T, Kingsbury Z, Sudbrak R, Albrecht MW, Amstislavskiy VS, Borodina TA, Lienhard M, Mertes F, Sultan M, Timmermann B, Yaspo M-L, et al. 2015. A global reference for human genetic variation. Nature 526:68-74.

Badura A, Schonewille M, Voges K, Galliano E, Renier N, Gao Z, Witter L, Hoebeek FE, Chédotal A, De Zeeuw Cl. 2013. Climbing Fiber Input Shapes Reciprocity of Purkinje Cell Firing. Neuron 78:700-713.

Barber M, Di Meglio T, Andrews WD, Hernández-Miranda LR, Murakami F, Chédotal A, Parnavelas JG. 2009. The role of Robo3 in the development 
of cortical interneurons. Cereb cortex 19 Suppl 1:i22-31.

Belle M, Godefroy D, Dominici C, Heitz-Marchaland C, Zelina P, Hellal F, Bradke F, Chédotal A. 2014. A Simple Method for 3D Analysis of Immunolabeled Axonal Tracts in a Transparent Nervous System. Cell Rep 9:1191-1201.

Di Bonito M, Narita Y, Avallone B, Sequino L, Mancuso M, Andolfi G, Franzè AM, Puelles L, Rijli FM, Studer M. 2013. Assembly of the auditory circuitry by a hox genetic network in the mouse brainstem. PLoS Genet 9:e1003249.

Borst JGG, Soria van Hoeve J. 2012. The calyx of held synapse: from model synapse to auditory relay. Annu Rev Physiol 74:199-224.

Bosley TM, Salih MAM, Jen JC, Lin DDM, Oystreck D, Abu-Amero KK, MacDonald DB, Zayed Z Al, Dhalaan H Al, Kansu T, Stigsby B, Baloh RW. 2005. Neurologic features of horizontal gaze palsy and progressive scoliosis with mutations in ROBO3. Neurology 64:1196-203.

Bouvier J, Thoby-Brisson M, Renier N, Dubreuil V, Ericson J, Champagnat J, Pierani A, Chédotal A, Fortin G. 2010. Hindbrain interneurons and axon guidance signaling critical for breathing. Nat Neurosci 13:1066-74.

Brose K, Bland KS, Wang KH, Arnott D, Henzel W, Goodman CS, TessierLavigne M, Kidd T. 1999. Slit proteins bind Robo receptors and have an evolutionarily conserved role in repulsive axon guidance. Cell 96:795806.

Burgess HA, Johnson SL, Granato M. 2009. Unidirectional startle responses and disrupted left-right co-ordination of motor behaviors in robo3 mutant zebrafish. Genes, Brain Behav 8:500-511.

Camurri L, Mambetisaeva E, Sundaresan V. 2004. Rig-1 a new member of Robo family genes exhibits distinct pattern of expression during mouse development. Gene Expr patterns 4:99-103.

Camurri L, Mambetisaeva ET, Davies D, Parnavelas JG, Sundaresan V, 
Andrews WD. 2005. Evidence for the existence of two Robo3 isoforms with divergent biochemical properties. Mol Cell Neurosci 30:485-93.

Cariboni A, Andrews WD, Memi F, Ypsilanti AR, Zelina P, Chédotal A, Parnavelas JG. 2012. Slit2 and Robo3 modulate the migration of GnRHsecreting neurons. Development 139:3326-3331.

Challa AK, Beattie CE, Seeger M a. 2001. Identification and characterization of roundabout orthologs in zebrafish. Mech Dev 101:249-253.

Challa AK, McWhorter ML, Wang C, Seeger M a, Beattie CE. 2005. Robo3 isoforms have distinct roles during zebrafish development. Mech Dev 122:1073-86.

Chan W-M, Traboulsi El, Arthur B, Friedman N, Andrews C, Engle EC. 2006. Horizontal gaze palsy with progressive scoliosis can result from compound heterozygous mutations in ROBO3. J Med Genet 43.

Chédotal A. 2011. Further tales of the midline. Curr Opin Neurobiol 21:68-75.

Chédotal A. 2014. Development and plasticity of commissural circuits: from locomotion to brain repair. Trends Neurosci 37:551-62.

Chen Z, Gore BB, Long H, Ma L, Tessier-Lavigne M. 2008. Alternative splicing of the Robo3 axon guidance receptor governs the midline switch from attraction to repulsion. Neuron 58:325-32.

Colak D, Ji S-J, Porse BT, Jaffrey SR. 2013. Regulation of Axon Guidance by Compartmentalized Nonsense-Mediated mRNA Decay. Cell 153:12521265.

Comer JD, Pan FC, Willet SG, Haldipur P, Millen KJ, Wright CVE, Kaltschmidt $\mathrm{J}$ a. 2015. Sensory and spinal inhibitory dorsal midline crossing is independent of Robo3. Front Neural Circuits 9:1-14.

Crepel F, Mariani J, Delhaye-Bouchaud N. 1976. Evidence for a multiple innervation of Purkinje cells by climbing fibers in the immature rat cerebellum. J Neurobiol 7:567-78. 
Denk AE, Kaufmann S, Stark K, Schedel J, Lowin T, Schubert T, Bosserhoff AK. 2010. Slit3 inhibits Robo3-induced invasion of synovial fibroblasts in rheumatoid arthritis. Arthritis Res Ther 12:R45.

Devine CA, Key B. 2008. Robo-Slit interactions regulate longitudinal axon pathfinding in the embryonic vertebrate brain. Dev Biol 313:371-383.

Ding Q, Joshi P, Xie Z, Xiang M, Gan L. 2012. BARHL2 transcription factor regulates the ipsilateral/contralateral subtype divergence in postmitotic dl1 neurons of the developing spinal cord. Proc Natl Acad Sci U S A 109:1566-1571.

Escalante A, Murillo B, Morenilla-Palao C, Klar A, Herrera E. 2013. Zic2Dependent Axon Midline Avoidance Controls the Formation of Major Ipsilateral Tracts in the CNS. Neuron 80:1392-1406.

Evans T a, Bashaw GJ. 2010. Functional diversity of robo receptor immunoglobulin domains promotes distinct axon guidance decisions. Curr Biol 20:567-72.

Evans T a, Bashaw GJ. 2012. Slit/Robo-mediated axon guidance in Tribolium and Drosophila: Divergent genetic programs build insect nervous systems. Dev Biol 363:266-78.

Evans TA, Santiago C, Arbeille E, Bashaw GJ. 2015. Robo2 acts in trans to inhibit Slit-Robo1 repulsion in pre-crossing commissural axons. Elife 4:126.

Fernández-Vega Cueto A, Rodríguez-Ezcurra JJ, Rodríguez-Maiztegui I. 2016. Horizontal gaze palsy and progressive scoliosis in a patient with congenital esotropia and inability to abduct. A case report. Arch Soc Esp Oftalmol:4-7.

Geisen MJ, Di Meglio T, Pasqualetti M, Ducret S, Brunet J-F, Chédotal A, Rijli FM, Meglio T Di. 2008. Hox paralog group 2 genes control the migration of mouse pontine neurons through slit-robo signaling. Plos Biol 6:e142.

Goulding M. 2009. Circuits controlling vertebrate locomotion: moving in a new 
direction. Nat Rev Neurosci 10:507-18.

Granato M, van Eeden FJ, Schach U, Trowe T, Brand M, Furutani-Seiki M, Haffter P, Hammerschmidt M, Heisenberg CP, Jiang YJ, Kane D a, Kelsh RN, Mullins MC, Odenthal J, Nüsslein-Volhard C. 1996. Genes controlling and mediating locomotion behavior of the zebrafish embryo and larva. Development 123:399-413.

Haller S, Wetzel SG, Lütschg J. 2008. Functional MRI, DTI and neurophysiology in horizontal gaze palsy with progressive scoliosis. Neuroradiology 50:453-9.

Han S, Cao C, Tang T, Lu C, Xu J, Wang S, Xue L, Zhang X, Li M. 2015. ROBO3 promotes growth and metastasis of pancreatic carcinoma. Cancer Lett 366:61-70.

Hedgecock EM, Culotti JG, Hall DH. 1990. The unc-5, unc-6, and unc-40 genes guide circumferential migrations of pioneer axons and mesodermal cells on the epidermis in C. elegans. Neuron 4:61-85.

Hocking JC, Hehr CL, Bertolesi GE, Wu JY, McFarlane S. 2010. Distinct roles for Robo2 in the regulation of axon and dendrite growth by retinal ganglion cells. Mech Dev 127:36-48.

Hohenester E. 2008. Structural insight into Slit-Robo signalling. Biochem Soc Trans 36:251-6.

Huang H, Vasung L. 2014. Gaining insight of fetal brain development with diffusion MRI and histology. Int J Dev Neurosci 32:11-22.

Inamata Y, Shirasaki R. 2014. Dbx1 triggers crucial molecular programs required for midline crossing by midbrain commissural axons.

Development 141:1260-1271.

Jaworski A, Long H, Tessier-Lavigne M. 2010. Collaborative and Specialized Functions of Robo1 and Robo2 in Spinal Commissural Axon Guidance. J Neurosci 30:9445-9453.

Jaworski A, Tom I, Tong RK, Gildea HK, Koch AW, Gonzalez LC, Tessier- 
Lavigne M. 2015. Operational redundancy in axon guidance through the multifunctional receptor Robo3 and its ligand NELL2. Science 350:961965.

Jen J, Coulin CJ, Bosley TM, Salih MAM, Sabatti C, Nelson SF, Baloh RW. 2002. Familial horizontal gaze palsy with progressive scoliosis maps to chromosome 11q23-25. Neurology 59:432-435.

Jen JC, Chan W-MM, Bosley TM, Wan J, Carr JR, Rub U, Shattuck D, Salamon G, Kudo LC, Ou J, Lin DDM, Salih MAM, Kansu T, AI Dhalaan H, Al Zayed Z, MacDonald DB, Stigsby B, Plaitakis A, Dretakis EK, Gottlob I, Pieh C, Traboulsi El, Wang Q, Wang L, Andrews C, Yamada K, Demer JL, Karim S, Alger JR, Geschwind DH, Deller T, Sicotte NL, Nelson SF, Baloh RW, Engle EC, Rüb U. 2004. Mutations in a human ROBO gene disrupt hindbrain axon pathway crossing and morphogenesis. Science 304:1509-1513.

Kaneko N, Marín O, Koike M, Hirota Y, Uchiyama Y, Wu JY, Lu Q, TessierLavigne M, Alvarez-Buylla A, Okano H, Rubenstein JL, Sawamoto K. 2010. New Neurons Clear the Path of Astrocytic Processes for Their Rapid Migration in the Adult Brain. Neuron 67:213-223.

Karlstrom RO, Trowe T, Klostermann S, Baier H, Brand M, Crawford a D, Grunewald B, Haffter P, Hoffmann H, Meyer SU, Müller BK, Richter S, van Eeden FJ, Nüsslein-Volhard C, Bonhoeffer F. 1996. Zebrafish mutations affecting retinotectal axon pathfinding. Development 123:42738.

Keleman K, Rajagopalan S, Cleppien D, Teis D, Paiha K, Huber LA, Technau GM, Dickson BJ. 2002. Comm sorts robo to control axon guidance at the Drosophila midline. Cell 110:415-27.

Khan AO, Oystreck DT, Al-Tassan N, Al-Sharif L, Bosley TM. 2008. Bilateral Synergistic Convergence Associated with Homozygous ROB03 Mutation (p.Pro771Leu). Ophthalmology 115:2262-2265.

Kidd T, Bland KS, Goodman CS. 1999. Slit is the midline repellent for the robo 
receptor in Drosophila. Cell 96:785-794.

Kidd T, Brose K, Mitchell KJ, Fetter RD, Tessier-Lavigne M, Goodman CS, Tear G. 1998. Roundabout controls axon crossing of the CNS midline and defines a novel subfamily of evolutionarily conserved guidance receptors. Cell 92:205-215.

Kuwako K, Kakumoto K, Imai T, Igarashi M, Hamakubo T, Sakakibara S, Tessier-Lavigne M, Okano HHJJ. 2010. Neural RNA-binding protein Musashi1 controls midline crossing of precerebellar neurons through posttranscriptional regulation of Robo3/Rig-1 expression. Neuron 67:407-421.

Lee JS, Ray R, Chien CB. 2001. Cloning and expression of three zebrafish roundabout homologs suggest roles in axon guidance and cell migration. Dev Dyn 221:216-30.

Li L, Liu S, Lei Y, Cheng Y, Yao C, Zhen X. 2014. Robo3.1A suppresses Slitmediated repulsion by triggering degradation of Robo2. J Neurosci Res 92:835-846.

Mambetisaeva ET, Andrews WD, Camurri L, Annan A, Sundaresan V. 2005. Robo family of proteins exhibit differential expression in mouse spinal cord and Robo-Slit interaction is required for midline crossing in vertebrate spinal cord. Dev Dyn 233:41-51.

Marcos-Mondejar P, Peregrin S, Li JY, Carlsson L, Tole S, Lopez-Bendito G. 2012. The Lhx2 Transcription Factor Controls Thalamocortical Axonal Guidance by Specific Regulation of Robo1 and Robo2 Receptors. J Neurosci 32:4372-4385.

Marillat V, Chédotal A, Cases O, Nguyen-Ba-Charvet KT, Tessier-Lavigne M, Sotelo C. 2002. Spatiotemporal expression patterns of slit and robo genes in the rat brain. J Comp Neurol 442:130-155.

Marillat V, Sabatier C, Failli V, Matsunaga E, Sotelo C, Tessier-Lavigne M, Chédotal A. 2004. The slit receptor Rig-1/Robo3 controls midline crossing by hindbrain precerebellar neurons and axons. Neuron 43:69-79. 
Marion J-F, Yang C, Caqueret A, Boucher F, Michaud JL. 2005. Sim1 and Sim2 are required for the correct targeting of mammillary body axons. Development 132:5527-37.

Di Meglio T, Nguyen-Ba-Charvet KT, Tessier-Lavigne M, Sotelo C, Meglio T Di, Chédotal A. 2008. Molecular mechanisms controlling midline crossing by precerebellar neurons. J Neurosci 28:6285-94.

Meneret a., Welniarz Q, Trouillard O, Roze E. 2015. Congenital mirror movements: From piano player to opera singer. Neurology 84:860-860.

Michalski N, Babai N, Renier N, Perkel DJJ, Chédotal A, Schneggenburger R. 2013. Robo3-Driven Axon Midline Crossing Conditions Functional Maturation of a Large Commissural Synapse. Neuron 78:855-868.

Moran-Rivard L, Kagawa T, Saueressig H, Gross MK, Burrill J, Goulding M. 2001. Evx1 is a postmitotic determinant of $\mathrm{V} 0$ interneuron identity in the spinal cord. Neuron 29:385-399.

Necsulea a, Kaessmann H. 2014. Evolutionary dynamics of coding and noncoding transcriptomes. Nat Rev Genet 15:734-748.

Neveu MM, Jeffery G. 2007. Chiasm formation in man is fundamentally different from that in the mouse. Eye 21:1264-1270.

Ng ASL, Sitoh Y-Y, Zhao Y, Teng EWL, Tan EK, Tan LCS. 2011. Ipsilateral stroke in a patient with horizontal gaze palsy with progressive scoliosis and a subcortical infarct. Stroke 42:e1-3.

Nguyen-Ba-Charvet KT, Picard-Riera N, Tessier-Lavigne M, Baron-Van Evercooren A, Sotelo C, Chédotal A. 2004. Multiple roles for slits in the control of cell migration in the rostral migratory stream. $J$ Neurosci 24:1497-506.

Ouellet J, Odent T. 2013. Animal models for scoliosis research: state of the art, current concepts and future perspective applications. Eur spine $\mathrm{J} 22$ Suppl 2:S81-95.

Paul LK. 2011. Developmental malformation of the corpus callosum: a review 
of typical callosal development and examples of developmental disorders with callosal involvement. J Neurodev Disord 3:3-27.

Pierani A, Moran-Rivard L, Sunshine MJ, Littman DR, Goulding M, Jessell TM. 2001. Control of interneuron fate in the developing spinal cord by the progenitor homeodomain protein Dbx1. Neuron 29:367-384.

Rajagopalan S, Nicolas E, Vivancos V, Berger J, Dickson BJ. 2000. Crossing the midline: roles and regulation of robo receptors. Neuron 28:767-777.

Renier N, Schonewille M, Giraudet F, Badura A, Tessier-Lavigne M, Avan P, De Zeeuw Cl, Chédotal A. 2010. Genetic Dissection of the Function of Hindbrain Axonal Commissures. PLoS Biol 8:e1000325.

Sabatier C, Plump AS, Le Ma, Brose K, Tamada A, Murakami F, Lee EY-HP, Tessier-Lavigne M. 2004. The divergent Robo family protein rig-1/Robo3 is a negative regulator of slit responsiveness required for midline crossing by commissural axons. Cell 117:157-69.

Samelson BK, Gore BB, Whiting JL, Nygren PJ, Purkey AM, Colledge M, Langeberg LK, Dell'Acqua ML, Zweifel LS, Scott JD. 2015. A-Kinase Anchoring Protein 79/150 recruits Protein Kinase $C$ to phosphorylate Roundabout receptors. J Biol Chem:jbc.M115.637470.

Schweitzer J, Lohr H, Bonkowsky JL, Hubscher K, Driever W, Löhr H, Hübscher K. 2013. Sim1a and Arnt2 contribute to hypothalamo-spinal axon guidance by regulating Robo2 activity via a Robo3-dependent mechanism. Development 140:93-106.

Seeger M, Tear G, Ferres-Marco D, Goodman CS. 1993. Mutations affecting growth cone guidance in Drosophila: genes necessary for guidance toward or away from the midline. Neuron 10:409-26.

Shiraki A, Saito F, Akane H, Akahori Y, Imatanaka N, Itahashi M, Yoshida T, Shibutani M. 2016. Gene expression profiling of the hippocampal dentate gyrus in an adult toxicity study captures a variety of neurodevelopmental dysfunctions in rat models of hypothyroidism. J Appl Toxicol 36:24-34. 
Sicotte NL, Salamon G, Shattuck DW, Hageman N, Rüb U, Salamon N, Drain a E, Demer JL, Engle EC, Alger JR, Baloh RW, Deller T, Jen JC, Rüb U. 2006. Diffusion tensor MRI shows abnormal brainstem crossing fibers associated with ROBO3 mutations. Neurology 67:519-21.

Stielow B, Kruger I, Diezko R, Finkernagel F, Gillemans N, Kong-a-San J, Philipsen S, Suske G. 2010. Epigenetic silencing of spermatocytespecific and neuronal genes by SUMO modification of the transcription factor sp3. PLoS Genet 6:1-9.

Suda S, Iwata K, Shimmura C, Kameno Y, Anitha A, Thanseem I, Nakamura K, Matsuzaki H, Tsuchiya KJ, Sugihara G, Iwata Y, Suzuki K, Koizumi K, Higashida H, Takei N, Mori N. 2011. Decreased expression of axonguidance receptors in the anterior cingulate cortex in autism. Mol Autism $2: 14$

Sundaresan V, Mambetisaeva E, Andrews W, Annan A, Knöll B, Tear G, Bannister L. 2004. Dynamic expression patterns of Robo (Robo1 and Robo2) in the developing murine central nervous system. J Comp Neurol 468:467-81.

Tamada A, Kumada T, Zhu Y, Matsumoto T, Hatanaka Y, Muguruma K, Chen Z, Tanabe Y, Torigoe M, Yamauchi K, Oyama H, Nishida K, Murakami F. 2008. Crucial roles of Robo proteins in midline crossing of cerebellofugal axons and lack of their up-regulation after midline crossing. Neural Dev 3:29.

Tessier-Lavigne M, Goodman CS. 1996. The molecular biology of axon guidance. Science 274:1123-1133.

Torres M, Gómez-Pardo E, Dressler GR, Gruss P. 1995. Pax-2 controls multiple steps of urogenital development. Development 121:4057-4065.

Valin A, Gill G. 2013. Enforcing the pause; Transcription factor Sp3 limits productive elongation by RNA polymerase II. Cell Cycle 12:1828-1834.

Volk AE, Carter O, Fricke J, Herkenrath P, Poggenborg J, Borck G, Demant AW, Ivo R, Eysel P, Kubisch C, Neugebauer A. 2011. Horizontal gaze 
palsy with progressive scoliosis: Three novel $\mathrm{ROBO} 3$ mutations and descriptions of the phenotypes of four patients. Mol Vis 17:1978-86.

Wang Z, Hou Y, Guo X, van der Voet M, Boxem M, Dixon JEE, Chisholm ADD, Jin Y, van der Voet M. 2013. The EBAX-type Cullin-RING E3 Ligase and Hsp90 Guard the Protein Quality of the SAX-3/Robo Receptor in Developing Neurons. Neuron 79:903-916.

Wehr R, Gruss P. 1996. Pax and vertebrate development. Int J Dev Biol 40:369-377.

Wilson SI, Shafer B, Lee KJ, Dodd J. 2008. A molecular program for contralateral trajectory: Rig-1 control by LIM homeodomain transcription factors. Neuron 59:413-24.

Wong GKW, Baudet M-L, Norden C, Leung L, Harris WA. 2012. Slit1b-robo3 signaling and $\mathrm{N}$-cadherin regulate apical process retraction in developing retinal ganglion cells. J Neurosci 32:223-8.

Yamada S, Okita Y, Shofuda T, Yoshioka E, Nonaka M, Mori K, Nakajima S, Kanemura Y. 2015. Ipsilateral hemiparesis caused by putaminal hemorrhage in a patient with horizontal gaze palsy with progressive scoliosis: a case report. BMC Neurol 15:25.

Ypsilanti AR, Zagar Y, Chédotal A. 2010. Moving away from the midline: new developments for Slit and Robo. Development 137:1939-52.

Yuan S-SF, Yeh Y-T, Lee EY-HP. 2002. Pax-2 interacts with RB and reverses its repression on the promoter of Rig-1, a Robo member. Biochem Biophys Res Commun 296:1019-1025.

Yuan SS, Cox L a, Dasika GK, Lee EY-HP. 1999. Cloning and functional studies of a novel gene aberrantly expressed in RB-deficient embryos. Dev Biol 207:62-75.

Zakrys L, Ward RJ, Pedani JD, Godin AG, Graham GJ, Milligan G. 2014. Roundabout 1 exists predominantly as a basal dimeric complex and this is unaffected by binding of the ligand Slit2. Biochem J:in press. 
Zelina P, Blockus H, Zagar Y, Péres A, Friocourt F, Wu Z, Rama N, Fouquet

C, Hohenester E, Tessier-Lavigne M, Schweitzer J, Crollius HR, Chédotal A. 2014. Signaling Switch of the Axon Guidance Receptor Robo3 during Vertebrate Evolution. Neuron 84:1-15.

\section{Figures legends}

Figure 1: Robo3 receptor structure and evolution. A. Robo3 receptor is composed of 5 immunoglobulin domains ( $\lg 1-5)$, 3 fibronectin type III domains (Fnlll1-3) and an intracellular domain containing 3 or 4 cytoplasmic conserved motifs (CC). B. Robo3 belongs to Robo family of receptors, which are present in all bilateria. There are 4 Robo genes in vertebrates, all deriving from a common ancestral Robo sequence. C. Vertebrate Robo receptors display conserved features including highly conserved lg1 domain involved in Slit binding, and cytoplasmic domains involved in intracellular signaling. However, mammalian Robo3 receptors differ from other Robos on these two aspects with numerous mutations in the Ig1 domain, related to loss of Slit binding, and intracellular modifications including a $\mathrm{CCO}$ domain loss (identified by a red star). Percentages indicate amino acid identity between Robo lg1 domains.

Figure 2: Robo3 expression and function in commissural axons in the mammalian nervous system. A. Immunostaining against Robo3 (in green) and Neurofilament (NF, in magenta) in a mouse embryo spinal cord (E11). Robo3 expression is restricted to commissural projections before they cross the midline. B. Dual mechanisms of action proposed for Robo3 in commissural axon guidance. Commissural neurons are attracted to the midline, which is secreting multiple guidance molecules including Netrin-1 and Slit proteins. In the anti-repulsive model, Robo3 inhibits Slit/Robo1/2-mediated midline repulsion. In the pro-attractive model, Robo3 potentiates Netrin-1 attractive signaling in cooperation with the Netrin-1 receptor DCC. 
Figure 3: Horizontal Gaze Palsy with Progressive Scoliosis (HGPPS) is associated with $\mathrm{ROBO} 3$ mutations and commissural defects. A. Signature symptoms of HGPPS patients: A severe progressive scoliosis developing in childhood, hypoplasia of basilar pons and absence of conjugate horizontal eye movements. Adapted with permission from Jen et al., 2004. B. $\mathrm{ROBO} 3$ mutations associated with HGPPS and their position along the $\mathrm{ROBO} 3$ protein. Missense mutations are presented by a red and yellow circle, Nonsense mutations by a red circle, Frameshift by a red star and splicing mutations by a brown hexagon. Complete list of $R O B O 3$ mutations and their amino acid equivalence is presented in Table 1. C. Comparison of horizontal gaze palsy in human HGPPS patients with vestibulo-ocular reflex defects in mice from two different conditional Robo3 knockout mouse lines: Pf1aCreRobo3lox and Krox20Cre-Robo3lox. D. Oculomotor network controlling horizontal eye movement involves many different commissural systems. Simultaneous activation of abducens nucleus and pre-optic nucleus (PO) results in conjugate contraction of LR (Lateral Rectus) from the right eye and MR (Medial Rectus) from the left eye, leading to conjugate lateral eye movement. Perturbation of this system induces horizontal eye movement defects similar to those observed in HGPPS patients. In Krox20Cre-Robo3lox mice, the median longitudinal fascicle (mlf) is disrupted; in Ptf1Cre-Robo3lox mice, inferior olivary neurons (IO) project to the ipsilateral cerebellum. Both defects are indicated by red stars. VN: Vestibular nucleus.

Figure 4: Robo3 receptor isoforms and their conservation in vertebrates.

A. Schematic representation of mouse Robo3 isoforms Robo3A, Robo3B, Robo3.1 and Robo3.2. B. Alternative intron 26 retention during mouse Robo3 splicing produces two different Robo3 mRNAs. Premature stop codon (red star) in intron 26 produces a truncated version of Robo3 receptor identified as Robo3.2. C. Alignment of vertebrate ROBO3.1 sequences from NCBI and Ensembl databases (references are listed in E) using ClustalW. Only Cterminal sequences are displayed, starting amino acid 1312 of human ROBO3A.1. Amino acids coded by exons 26 and 28 are presented over a blue background and amino acids coded by exon 27 over a green background. Amino acid conservation was calculated for each position using 
the alignment ; conservation index is represented in the graph below the alignment. D. ROBO3.2 sequences were produced from $\mathrm{ROBO}$ genomic sequences (references are listed in E) by translating exons 26 and following intron 26 until stop codon was reached (except from mouse Robo3.2 protein sequence already available on $\mathrm{NCBI}$ ). Vertebrate ROBO3.2 sequences were aligned using ClustalW. Only C-terminal sequences are displayed, starting amino acid 1312 of human ROBO3A.1. Amino acids coded by exon 26 are presented over a blue background and amino acids coded by intron 26 over a purple background. Red stars represent premature intron 26 stop codons. As for ROBO3.1, conservation index was calculated for each position using the alignment and represented in the graph below the alignment. E. References of sequences used for $\mathrm{ROBO} 3$ protein alignments. Genomic sequences references used for predicted $\mathrm{ROBO} .2$ translation are in italic.

Figure 5: Regulation of Robo3 expression in mammals. A. Transcriptional regulation of Robo3 expression. Multiple pathways have been described to regulate Robo3 expression, depending on commissural systems. Here are presented different transcriptional cascades leading either to Robo3 expression or silencing, respectively represented in green and yellow. B. Post-transcriptional regulation of Robo3 mRNA. In inferior olive neurons, Musashi protein binds to Robo3 mRNA and recruits it to heavy polysomes for high-level translation. Floor plate-mediated Musashi down-regulation would contribute to Robo3 expression decrease after midline crossing. In other commissural circuits, Musashi protein is absent and no protein have been associated yet with Robo3 post-transcriptional regulation. 
Table 1: HGPPS associated ROBO3 mutations. Nonsense mutations and frameshift mutations leading to premature stop codon and potentially truncated proteins are indicated in orange.

\begin{tabular}{|c|c|c|c|}
\hline $\begin{array}{l}\text { Nucleotide } \\
\text { change }\end{array}$ & $\begin{array}{|ll|}\begin{array}{l}\text { Amino } \\
\text { change }\end{array} & \text { acid } \\
\end{array}$ & Domain & Publication \\
\hline $14 \mathrm{~T}>\mathrm{C}$ & L5P & Nter & Jen et al., 2004 \\
\hline $196 \mathrm{~A}>\mathrm{C}$ & $166 \mathrm{~L}$ & $\lg 1$ & Jen et al., 2004; Wang et al., 2013 \\
\hline $271 \mathrm{C}>\mathrm{T}$ & P91S & $\lg 1$ & Abu-Amero et al., 2009 \\
\hline $283 C>T$ & 195T & $\lg 1$ & Amouri et al., 2009 \\
\hline $335 \mathrm{G}>\mathrm{C}$ & R112P & $\lg 1$ & Abu-Amero et al., 2009 \\
\hline $571 \mathrm{DelC}$ & Frameshift & $\lg 2$ & Abu-Amero et al., 2009 \\
\hline $733 \mathrm{C}>\mathrm{T}$ & R245W & $\lg 2-3$ & Chan et al., 2006; Amouri et al., 2009 \\
\hline 913 DelAinsTGC & Frameshift & $\lg 3$ & Volk et al., 2011 \\
\hline $955 \mathrm{G}>\mathrm{A}$ & E319K & $\lg 3$ & Jen et al., 2004; Amoiridis et al., 2006 \\
\hline $1082 \mathrm{G}>\mathrm{A}$ & G361E & $\overline{\lg 4}$ & Jen et al., 2004 \\
\hline $1158 \mathrm{G}>\mathrm{C}$ & Q386H & $\lg 4$ & Fernández-Vega Cueto et al. 2016 \\
\hline $1366 \mathrm{G}>\mathrm{T}$ & G456X & $\lg 4-5$ & Jen et al., 2004 \\
\hline $1379 A>G$ & Q460R & $\lg 5$ & Abu-Amero et al., 2009 \\
\hline $1450 \mathrm{~T}>\mathrm{C}$ & W484R & $\lg 5$ & Amouri et al., 2009 \\
\hline 1618 DelG & Frameshift & Fn III 1 & Amouri et al., 2009 \\
\hline $1726 \mathrm{~T}>\mathrm{C}$ & W576R & Fn III 1 & Abu-Amero et al., 2009 \\
\hline 1844-45 DelCA & Frameshift & Fn III 1 & Chan et al., 2006 \\
\hline 1886-87 DelTT & Frameshift & Fn III 1 & Chan et al., 2006 \\
\hline$E \times 13+1 G>A$ & Splicing defect & Fn III 2 & Jen et al., 2004 \\
\hline $2108 \mathrm{G}>\mathrm{C}$ & R703P & Fn III 2 & Jen et al., 2004; Haller et al., 2008 \\
\hline
\end{tabular}




\begin{tabular}{|c|c|c|c|}
\hline $2113 \mathrm{~T}>\mathrm{C}$ & S705P & Fn III 2 & Jen et al., 2004 \\
\hline 2310 InsC & Frameshift & Fn III 3 & Jen et al., 2004; Sicotte et al., 2006 \\
\hline $2312 \mathrm{C}>\mathrm{T}$ & P771L & Fn III 3 & Khan et al;; 2008 \\
\hline $2317 \mathrm{C}>\mathrm{T}$ & Q773X & Fn III 3 & Chan et al., 2006 \\
\hline $239 \mathrm{C}>\mathrm{T}$ & Q798X & Fn III 3 & Yamada et al., 2015 \\
\hline $\mathrm{G}>\mathrm{T}(\mathrm{Ex} 17)$ & $E-X$ & TM & Ng et al., 2011 \\
\hline $2663 \mathrm{~T}>\mathrm{C}$ & L888P & TM & Khan et al., 2014 \\
\hline $\begin{array}{lr}2769 & \text { Del31nt } \\
(11 \mathrm{Ex} 17 & + \\
20 \mathrm{Int} 17) & \\
\end{array}$ & $\begin{array}{l}\text { Splicing defect } \\
+ \text { frameshift }\end{array}$ & & Volk et al., 2011 \\
\hline $3319 A>C$ & $\begin{array}{l}\text { Ex22 skip + } \\
\text { frameshift }\end{array}$ & CC2-CC3 & Volk et al., 2011 \\
\hline 3325 InsG & frameshift & CC2-CC3 & Jen et al., 2004 \\
\hline
\end{tabular}




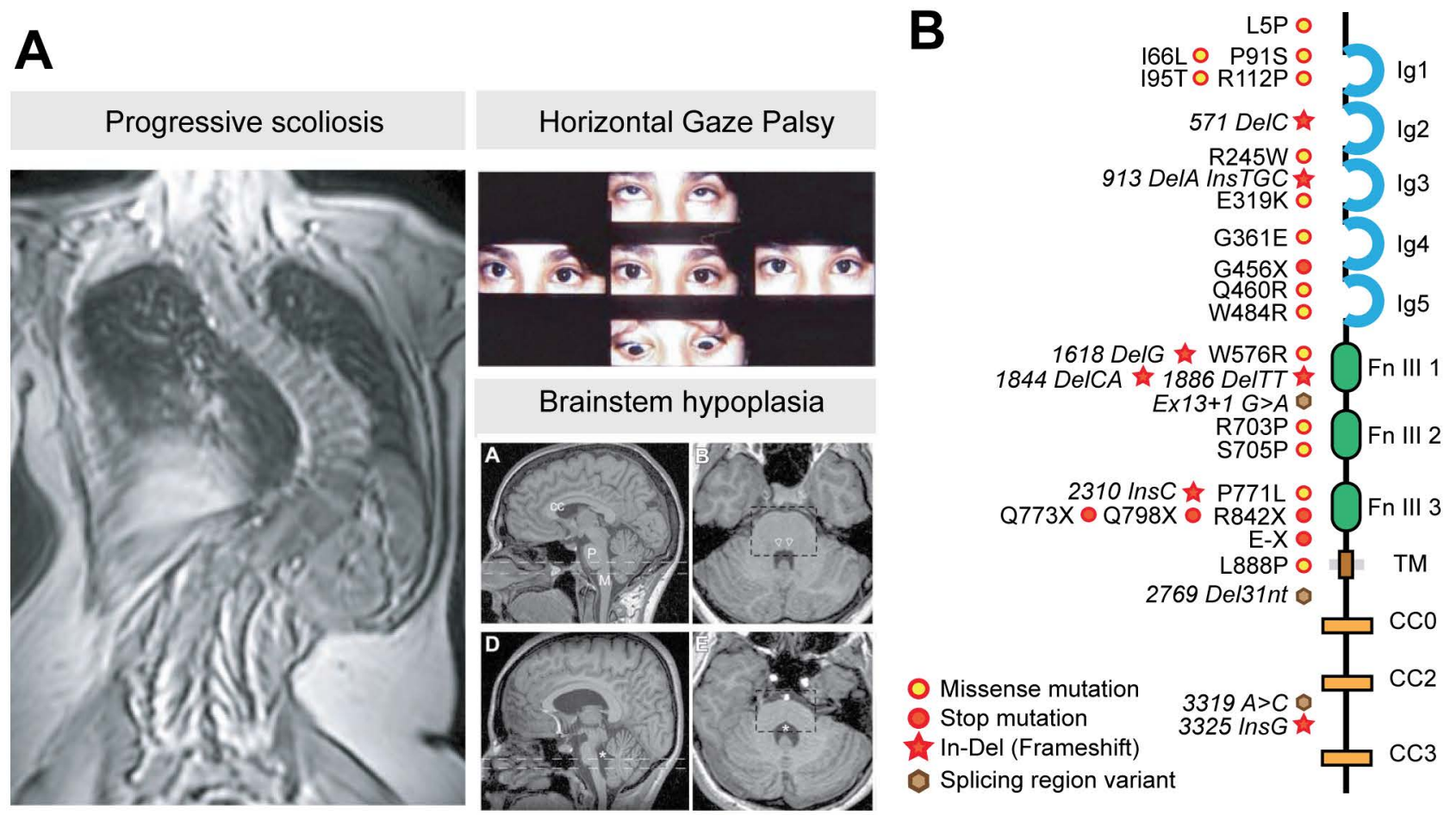

D

Control

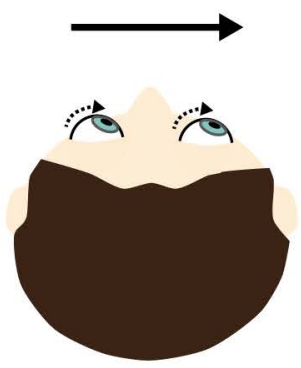

Control
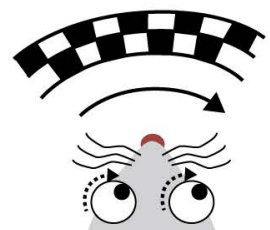

HGPPS

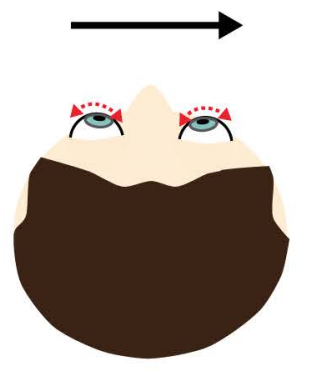

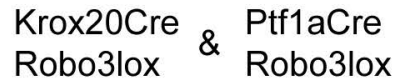

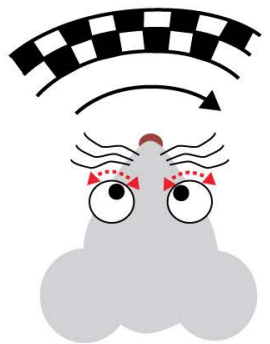

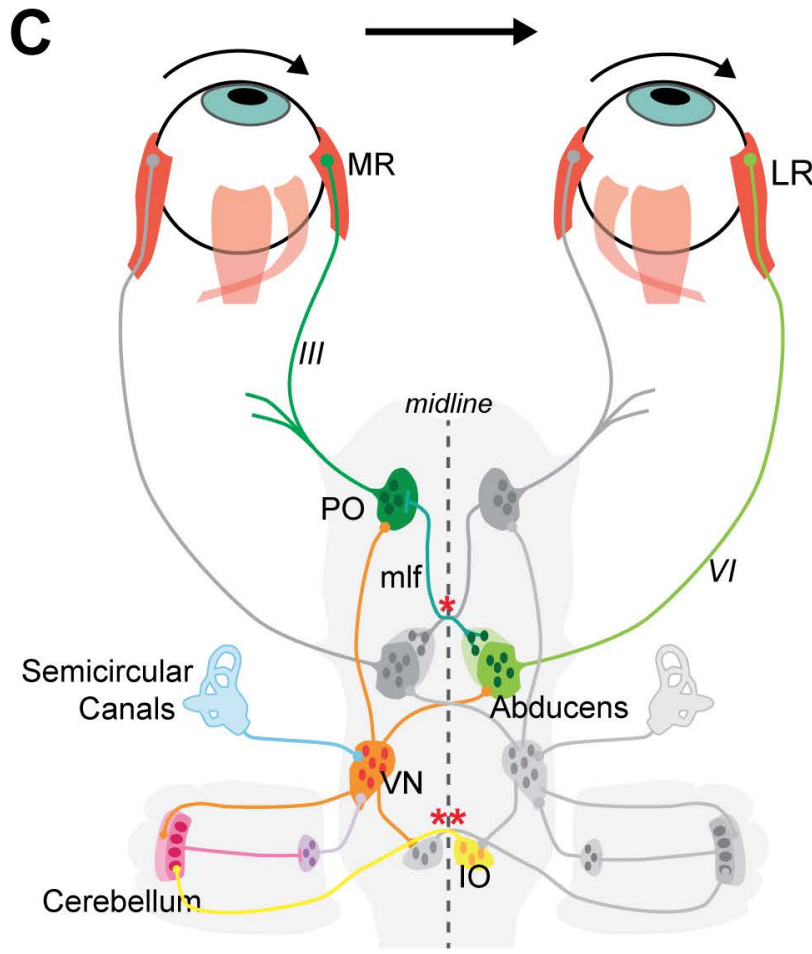

* disrupted in Krox20Cre,Robo3lox ** disrupted in Ptf1aCre,Robo3lox 
Heterochromatin (inactive)

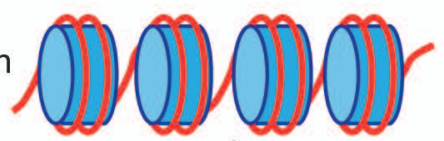
RB - - others?
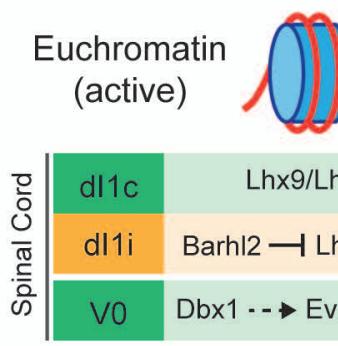

Lhx9/Lhx2 Barhl2 - Lhx2 - - -

F - - Zic2

dLB

$\mathrm{Dbx} 1 \rightarrow \mathrm{Evx} 1 / 2--?$

aVCN

Hoxa1 - - - - - -

$\mathrm{MBc}$

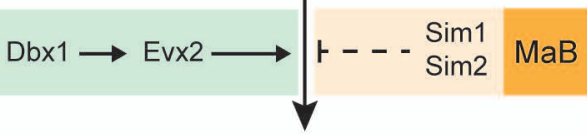

Robo3 mRNA
Robo3 mRNA

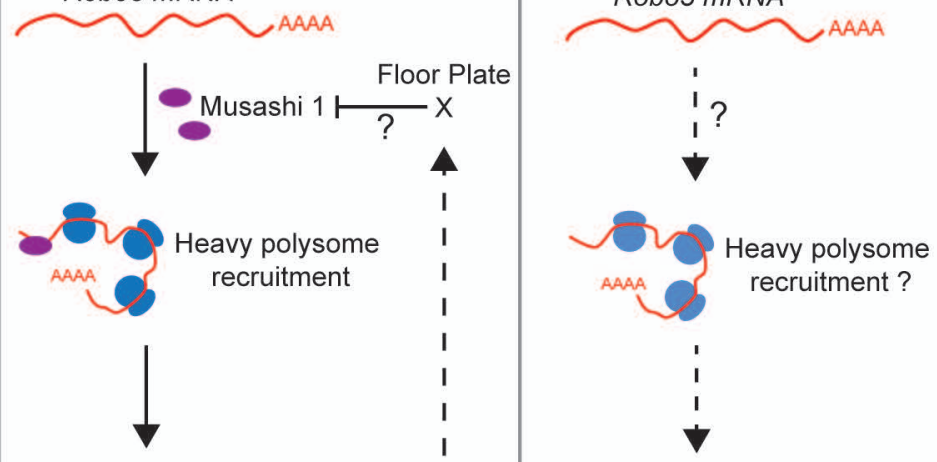

High Robo3 protein expression

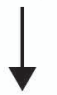

Midline attraction

IO, LRN and ECN
High Robo3 protein expression

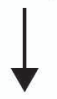

Midline attraction

Other commisural systems (Spinal cord, PN) 